\title{
A Longitudinal Study of Hematology and Stress Biomarker Profiles in Young Asian Elephants (Elephas maximus) in Relation to Elephant Endotheliotropic Herpesvirus (EEHV) in Thailand
}

\author{
Khajohnpat Boonprasert ${ }^{1}$, Yaoprapa Yun ${ }^{1}$, Worapong Kosaruk ${ }^{1}$ (D), Patcharapa Towiboon ${ }^{1}$, Pallop Tankaew ${ }^{1}$ \\ Veerasak Punyapornwithaya ${ }^{2,3}\left(\mathbb{D}\right.$, Thittaya Janyamathakul ${ }^{4}$, Panida Muanghong ${ }^{5}$, Janine L. Brown ${ }^{1,6} \mathbb{D}$, \\ Chatchote Thitaram ${ }^{1,7}$ and Chaleamchat Somgird ${ }^{1,7, *}$
}

Citation: Boonprasert, K.; Yun, Y.; Kosaruk, W.; Towiboon, P.; Tankaew, P.; Punyapornwithaya, V.; Janyamathakul, T.; Muanghong, P.; Brown, J.L.; Thitaram, C.; et al. A Longitudinal Study of Hematology and Stress Biomarker Profiles in Young Asian Elephants (Elephas maximus) in Relation to Elephant Endotheliotropic Herpesvirus (EEHV) in Thailand. Animals 2021, 11, 2530. https:// doi.org/10.3390/ani11092530

Academic Editor: Rita Tinoco Torres

Received: 2 August 2021

Accepted: 23 August 2021

Published: 28 August 2021

Publisher's Note: MDPI stays neutral with regard to jurisdictional claims in published maps and institutional affiliations.

Copyright: (c) 2021 by the authors. Licensee MDPI, Basel, Switzerland. This article is an open access article distributed under the terms and conditions of the Creative Commons Attribution (CC BY) license (https:// creativecommons.org/licenses/by/ $4.0 /)$.
1 Center of Elephant and Wildlife Research, Faculty of Veterinary Medicine, Chiang Mai University, Chiang Mai 50100, Thailand; khajohnpat@gmail.com (K.B.); yaoprapam@gmail.com (Y.Y.); woraph.kosa@gmail.com (W.K.); towiboon@gmail.com (P.T.); pallop_off@hotmail.com (P.T.); BrownJan@si.edu (J.L.B.); cthitaram@gmail.com (C.T.)

2 Department of Food Animal Clinic, Faculty of Veterinary Medicine, Chiang Mai University, Chiang Mai 50100, Thailand; pveerasak.r@gmail.com

3 Veterinary Public Health Centre and Food Safety for Asia Pacific (VPHCAP), Faculty of Veterinary Medicine, Chiang Mai University, Chiang Mai 50100, Thailand

4 Pattara Elephant Farm, Chiang Mai 50100, Thailand; thittayavet68@gmail.com

5 Mae Taeng Elephant Park and Clinic, Mae Thang, Chiang Mai 50150, Thailand; panida.vet72@hotmail.com

6 Center for Species Survival, Smithsonian Conservation Biology Institute, Front Royal, VA 22630, USA

7 Department of Companion Animal and Wildlife Clinics, Faculty of Veterinary Medicine, Chiang Mai University, Chiang Mai 50100, Thailand

* Correspondence: chaleamchat.s@cmu.ac.th; Tel.: +66-53-948015

Simple Summary: A change in hematology profiles is one indicator of EEHV infection before clinical signs appear; however, to be effective, individual baselines and age-matched reference values are needed. A longitudinal investigation of viremia, hematology values, and stress biomarkers was performed in three non-EEHV and six prior infected EEHV calves to better understand EEHVHD-associated factors. Blood, saliva, and feces were collected for 1 year for analysis of complete blood count (CBC), viral load, glucocorticoids (GCs), and Immunoglobulin A (IgA). Results did not differ between the groups, except for one elephant that presented with EEHV-HD during the study and exhibited high viremia, altered hematology profiles, and decreased stress biomarker concentrations. Thus, as in other studies, hematology changes were associated with EEHV infection, while preliminary data in one calf suggests that stress-response measures might also be informative and warrant further investigation.

Abstract: Elephant endotheliotropic herpesvirus hemorrhagic disease (EEHV-HD) is a virulent disease that causes severe hemorrhage and sudden death in Asian elephant calves. A change in hematology profiles is one indicator of infection before clinical signs appear; however, to be effective, individual baselines and age-matched reference values are needed. Stress has been speculated to be a factor in clinical EEHV cases, but relationships have not been demonstrated empirically. This study evaluated blood hematology and several stress response markers—salivary cortisol, fecal glucocorticoid metabolites (FGM), salivary Immunoglobulin A (SIgA), and fecal IgA (FIgA) in samples collected for 1 year from three healthy calves with no EEHV history (non-EEHV), and six that had previously been infected, developed clinical signs and survived (prior-EEHV). Hematology values between non-EEHV and prior-EEHV elephants were not different and within published reference ranges. Concentrations of salivary cortisol, FGM, SIgA, and FIgA also were variable and showed seasonal differences, but no relationships to prior EEHV status. One of the prior EEHV calves became re-infected, developed hemorrhagic disease (HD), and died during the study period. That calf exhibited lymphocytopenia, monocytopenia, and thrombocytopenia. Additionally, all stress biomarker concentrations were lower in the 12 days before viremia was observed. Thus, as in 
other studies, changes in hematology occur with EEHV infection, while preliminary data in one calf suggests that stress-response measures might also be informative and should be studied further.

Keywords: Asian elephant; hematology parameters; stress indicators; immunoglobulin A; glucocorticoids; elephant endotheliotropic herpesvirus

\section{Introduction}

Elephant endotheliotropic herpesvirus (EEHV) is a cause of the fatal hemorrhagic disease (HD) in Asian elephants worldwide and primarily affects calves [1,2]. Clinical signs include head and thoracic limb edema, lethargy, anorexia, and cyanosis of the tongue $[1,3]$. Death can occur quickly, within 1-7 days after clinical onset [4,5], with a mortality rate of up to $85 \%$ [1,6]. Identifying changes in blood hematology in response to EEHV infection are useful in diagnosing and monitoring disease progression [7], being detectable several days before clinical signs manifest [2,8,9]. Lymphopenia, monocytopenia, and thrombocytopenia are hallmarks of EEHV-HD viremia [2,8,10-12]. Thus, monitoring changes in white blood cell (WBC) counts is recognized as an important tool in the diagnosis of EEHV and assessing treatment efficacy in suspected cases [2,13].

To be most effective, a standard hematology profile is needed for each elephant to establish baseline values, as they can vary considerably $[2,14]$. Baseline values also are needed to detect often subtle changes after EEHV infection. Early detection of a drop in WBC compared to normal baseline can prove to be diagnostic and predictive for making rapid treatment decisions before clinical appearance [11,12], which improves treatment outcomes and survival [2]. To date, most hematology reference values in Asian elephants have been calculated on a population level [14-16], often with limited samples across age classes [2,11], and from elephants that differ in geography, nutrition, and management [17]. Therefore, establishing standard hematology values specific to clinically healthy young elephants could be useful for the assessment of suspected EEHV cases in this age category.

Similar to other viruses in the Herpesviridae family, EEHV can be symptomatic or asymptomatic [3,4,18-22]. Latent EEHV infections have been identified in the salivary gland and intestinal epithelial cell samples [23], with EEHV reactivation being hypothesized to be a result of an immunocompromised state, potentially related to stress [1]. For example, associations have been found between EEHV infections and weaning or training in the 30 days leading up to infection [24]. Physiological stress also has been implicated in increasing the susceptibility of young calves to EEHV infection and risk of developing EEHV-HD [18,25], although the mechanisms are not well understood.

Studies in zoo elephants have characterized cortisol patterns, finding higher concentrations in males than females due to management differences [14] and in cycling compared to non-cycling females [26]. Cortisol is a product of the hypothalamic-pituitary-adrenal axis, which is activated at times of physical or physiological stress [1,27-29]. As such, it is widely used as a biological indicator of the stress response and welfare state in many species [28], including Asian elephants [30-35]. However, data on how stressful events, such as transportation, pregnancy, weaning, husbandry, and management changes are related to clinical EEHV activation and cortisol secretion are lacking.

IgA is another potential biomarker of health and welfare [36] and is found in many secretory fluids, including saliva, breast milk, and nasal, gastrointestinal, bronchial, and urogenital secretions [37]. IgA is the first line of immune defense at the mucosal surfaces of the gastrointestinal, respiratory, and genitourinary tracts, where more than $95 \%$ of infections are initiated [38]. In animals, restraint and isolation have been associated with lower IgA [39,40], whereas higher concentrations were indicative of a positive welfare state [36,41,42].

While changes in hematology are known to be useful prognostic indicators of EEHV infection before clinical signs appear [2,4,12], clear links between EEHV status and stress 
biomarkers like glucocorticoids or IgA have not been established. This study explored links between viremia and hematology profiles, in addition to several stress-response measures-salivary cortisol (SC), FGM, salivary IgA (SIgA), and fecal IgA (FIgA) in Asian elephant calves. The goal was to improve our understanding of factors associated with EEHV viremia and provide more diagnostic tools to predict survival outcomes.

\section{Materials and Methods}

\subsection{Elephants and Sample Collection}

All animal procedures were approved by the Institutional Animal Care and Use Committee, Faculty of Veterinary Medicine, Chiang Mai University, Chiang Mai, Thailand (reference number S2/2562). Nine juvenile Asian calves from elephant camps in Chiang Mai, Thailand were included in this study, with an average age of $49.0 \pm 7.1$ months. Elephant calves were categorized as (1) 'non-EEHV', which consisted of three calves aged $56.0 \pm 4.0$ months (range 48-60 months) that did not have a history of EEHV infection based on medical records, and were not viremic based on real-time PCR in the month before study onset; and (2) 'prior-EEHV', comprised of six elephant calves aged $45.5 \pm 10.5$ months (range 20-78 months) that had previously tested positive for EEHV by blood PCR and presented clinical signs of EEHV-HD, but were not viremic in the month before study onset. One elephant in the second group tested positive again for EEHV, showed clinical signs, and died during the study period. Elephants received general health checks from a veterinarian before and during the study. Calves in the study had been weaned before study onset, with an average weaning age of $25.5 \pm 3.8$ months. Calves were fed Bana grass, sugarcane, banana, and banana tree. All lived in their natal camp, except one (E4) that was moved about $600 \mathrm{~km}$ from the northeastern to the northern region of Thailand at the age of 17 months (about 2 months after weaning). That animal was diagnosed with EEHV 11 months after arriving at the new facility and 7 months prior to this study. General information about the elephants in this study is summarized in Table 1.

\subsection{Blood Collection}

Blood samples were collected from an auricular vein once a month from December 2018-November 2019, after salivary and fecal collection to prevent increased cortisol concentrations due to restraint [1,29]. Blood was collected into EDTA anticoagulant tubes for hematology and EEHV real-time PCR analyses. Samples were chilled at $4{ }^{\circ} \mathrm{C}$ immediately after collection and transferred to the Veterinary Diagnosis Center, Faculty of Veterinary Medicine, Chiang Mai University for analysis.

\subsection{Saliva and Fecal Analysis}

Saliva and fecal samples were collected twice a month during the 2nd and 4th week between 10.00-12.00 h, to avoid variation in circadian rhythms of cortisol [33,43]. Saliva was collected using a Salivette ${ }^{\circledR}$ kit (Sarstedt, AG\&Co, Numbrecht, Germany) and harvested by centrifuging at $1500 \times g$ for 2 min at $15^{\circ} \mathrm{C}$ [42]. Fecal balls were mixed and approximately $20 \mathrm{~g}$ was collected into two separate zip-lock bags. All samples were transported in a $2-8{ }^{\circ} \mathrm{C}$ container box [42] to the Faculty of Veterinary Medicine, Chiang Mai University. All samples were stored at $-20^{\circ} \mathrm{C}$ until analysis $[42,44,45]$. Fecal samples were extracted as described previously for GCs $[34,42]$ and $\operatorname{IgA}[42,46]$.

\subsection{Salivary Cortisol and FGM Analyses}

Salivary cortisol concentrations were measured by a double-antibody enzyme immunoassay (EIA) using a secondary goat anti-rabbit IgG antibody and polyclonal rabbit anti-cortisol antibody (R4866, Coralie Munro, University of California Davis, Davis, CA, USA) validated for elephants [42,44]. 
Table 1. Information on the elephant calves in the study and the EEHV history.

\begin{tabular}{|c|c|c|c|c|c|c|c|c|c|c|c|}
\hline \multirow[b]{2}{*}{ ID } & \multirow[b]{2}{*}{ Camp } & \multirow[b]{2}{*}{ Gender } & \multirow{2}{*}{$\begin{array}{l}\text { Weaning Age } \\
\text { (Months) }\end{array}$} & \multirow{2}{*}{$\begin{array}{l}\text { Age at Start of } \\
\text { Study } \\
\text { (Months) }\end{array}$} & \multirow{2}{*}{$\begin{array}{l}\text { EEHV } \\
\text { Category }\end{array}$} & \multicolumn{4}{|c|}{ Detection of EEHV } & \multirow{2}{*}{$\begin{array}{l}\text { EEHV } \\
\text { Subtype }\end{array}$} & \multirow[b]{2}{*}{ Clinical Signs and Treatment } \\
\hline & & & & & & Date & Age (Months) & Test & $\begin{array}{l}\text { Highest Viral } \\
\text { Load (vgc/mL) }\end{array}$ & & \\
\hline \multirow[b]{2}{*}{ E1 } & \multirow[b]{2}{*}{$\mathrm{A}$} & \multirow[b]{2}{*}{ Female } & \multirow[b]{2}{*}{36} & \multirow[b]{2}{*}{77} & \multirow[b]{2}{*}{ Prior-EEHV ${ }^{1}$} & \multirow[b]{2}{*}{ July 2017} & \multirow[b]{2}{*}{60} & \multirow[b]{2}{*}{$\begin{array}{l}\text { Conventional } \\
\text { PCR }\end{array}$} & \multirow[b]{2}{*}{ negative } & \multirow[b]{2}{*}{4} & Signs: Depression and diarrhea \\
\hline & & & & & & & & & & & $\begin{array}{c}\text { Tx: Acyclovir, fluids, and } \\
\text { supportive therapies }{ }^{4}\end{array}$ \\
\hline E2 & B & Male & 30 & 60 & Non-EEHV $^{2}$ & & & & & $\mathrm{~N} / \mathrm{A}$ & $\mathrm{N} / \mathrm{A}$ \\
\hline \multirow{2}{*}{ E3 } & \multirow{2}{*}{$\mathrm{C}$} & \multirow{2}{*}{ Female } & \multirow{2}{*}{30} & \multirow{2}{*}{39} & \multirow{2}{*}{ Prior-EEHV } & \multirow{2}{*}{ October 2018} & \multirow{2}{*}{36} & \multirow{2}{*}{ Real-time PCR } & \multirow{2}{*}{$1,152,837$} & \multirow{2}{*}{$1 \mathrm{~A}$} & $\begin{array}{l}\text { Signs: Lethargy, depression, and } \\
\text { facial edema }\end{array}$ \\
\hline & & & & & & & & & & & $\begin{array}{l}\text { Tx: Acyclovir, fluids, and } \\
\text { supportive therapies }{ }^{4}\end{array}$ \\
\hline \multirow[b]{2}{*}{$\mathrm{E} 4$} & \multirow[b]{2}{*}{$\mathrm{D}$} & & & & & & & & & & Signs: Depressing and diarrhea \\
\hline & & Female & 15 & 35 & Prior-EEHV & July 2018 & 28 & Real-time PCR & 25,607 & 4 & $\begin{array}{l}\text { Tx: Acyclovir, fluids, and } \\
\text { supportive therapies }{ }^{4}\end{array}$ \\
\hline & & & & & & & & & & & 1st infection \\
\hline & & & & & & & & & & & $\begin{array}{l}\text { Signs: Lethargy, depression, and } \\
\text { facial edema }\end{array}$ \\
\hline E5 & E & Male & 12 & 20 & Prior-EEHV ${ }^{3}$ & June 2019 & 14 and 26 & Real-time PCR & $6,902,328$ & $1 \mathrm{~A}$ & 2nd infection \\
\hline & & & & & & & & & & & $\begin{array}{l}\text { Signs: Lethargy, depression, fever, } \\
\text { and facial edema, diarrhea }\end{array}$ \\
\hline & & & & & & & & & & & $\begin{array}{l}\text { Tx: Acyclovir, fluids, and } \\
\text { supportive therapies }{ }^{4}\end{array}$ \\
\hline & & & & & & J 2010 & & Conventional & nogative & & Signs: Depression and diarrhea \\
\hline E6 & A & Female & 35 & 78 & Prior-EEHV & Juiy 2018 & 72 & PCR & negative & 4 & $\begin{array}{l}\text { Tx: Acyclovir, fluids, and } \\
\text { supportive therapies }{ }^{4}\end{array}$ \\
\hline & & & & & & & & & & & Signs: Depression and diarrhea \\
\hline E7 & $\mathrm{F}$ & Male & 12 & 24 & Prior-EEHV & July 2018 & 18 & Real-time PCR & $1,306,864$ & 4 & $\begin{array}{l}\text { Tx: Acyclovir, fluids, and } \\
\text { supportive therapies }{ }^{4}\end{array}$ \\
\hline E8 & B & Male & 34 & 60 & Non-EEHV & & & & & $\mathrm{N} / \mathrm{A}$ & $\mathrm{N} / \mathrm{A}$ \\
\hline E9 & B & Male & 34 & 48 & Non-EEHV & & & & & $\mathrm{N} / \mathrm{A}$ & N/A \\
\hline
\end{tabular}

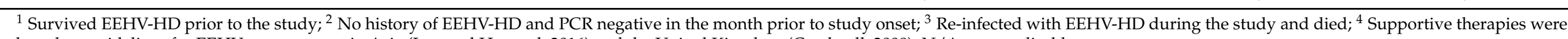
based on guidelines for EEHV management in Asia (Luz and Howard, 2016) and the United Kingdom (Cracknell, 2008); N/A, not applicable. 


\subsection{SIgA and FIgA Analyses}

IgA in salivary and fecal samples was measured using commercially available components as described by Edwards et al. [46] with some modifications as described by Plangsangmas et al. [44] and Kosaruk et al. [42].

\subsection{EEHV Analysis}

Whole blood samples were processed within $24 \mathrm{~h}$ after collection using a commercial kit (NucleoSpin ${ }^{\circledR}$, Macherey-Nagel GmbH \& Co. KG, Dueren, Germany) in accordance with the manufacturer's recommended protocol for $200 \mu \mathrm{L}$ of whole blood, and extracted DNA was eluted in $100 \mu \mathrm{L}$ of elution buffer. Concentrations of DNA were calculated by use of a spectrophotometer [9].

All DNA samples were screened for EEHV1 and EEHV4 using quantitative real-time PCR. Primers for genes U38 (polymerase), U39 (glycoprotein B), and U40 (Terminase) specific to EEHV1 and EEHV4 were designed and synthesized. The quantification of EEHV DNA was performed in duplicate on ABI 7300 Real-Time PCR System equipped with SDS Software v1.4 (Life Technologies, Darmstadt, Germany).

RT-PCR was performed using SensiFAST SYBR Hi-ROX Kit (Bioline, London, UK) as per the manufacturer's instruction. The cycling conditions were set as follows: an initial denaturation of $95^{\circ} \mathrm{C}$ for $2 \mathrm{~min}$, followed by 40 cycles of denaturation at $95^{\circ} \mathrm{C}$ for $5 \mathrm{~s}$, and annealing/extension at $60^{\circ} \mathrm{C}$ for $30 \mathrm{~s}$ in every tested gene. Subsequently, specificity was confirmed by dissociation curve analysis $(\mathrm{Tm})$. Correct product sizes were also determined by $2 \%$ agarose gel in $0.5 \times$ tris-acetate-ethylenediaminetetraacetic acid (TAE) buffer at $100 \mathrm{~V}$ for $35 \mathrm{~min}$. The gels were stained with ethidium bromide $(0.5 \mu \mathrm{g} / \mathrm{mL})$ were used to check real-time PCR product specificity. Samples that gave a PCR product of the expected size with all primer pairs, as determined by gel electrophoresis, will be classified as EEHV1 or EEHV4 positive [47].

The EEHV1 and EEHV4 genome copy numbers measured during the quantitative real-time PCR process for EEHV and genomic TNF $\alpha$ were first normalized against the spiked internal control to compensate for differences in nucleic acid extraction efficiency for each blood sample. The EEHV1 and EEHV4 genome copies for each blood sample were then normalized against those of genomic TNF $\alpha$ performed in parallel with $1 \mu \mathrm{g}$ of extracted DNA [48].

\subsection{Statistical Analysis}

$\mathrm{R}$ statistical software v3.5.1 was used to conduct all statistical analyses in this study. Data were averaged by season: summer (mid-February to mid-May); rainy (mid-May to mid-October); winter (mid-October to mid-February) followed by the Meteorological Department of Thailand (www.tmd.go.th, accessed on 12 July 2020). Normality and variance of the data were examined by $Q Q$ plot ( $R$ package: Quantile-Quantile plot 0.0.4; qqplotr) [49]. Mean data for hematology parameters and stress indicator concentrations are shown as a mean \pm standard error of the mean (SEM). Hematology values and stress indicator concentrations from healthy elephants with no clinical signs of illness during the study period (all except E5) were used to calculate normal reference values. Repeated measures data were analyzed using the Generalized Least Squares method (GLS, R package: non-linear mixed effect model 3.1-148; nlme [50]) to determine the effects of infection status and season factors on hematology values and stress indicator concentrations. Tukey's multiple comparisons of the least-squares mean (LS-mean) were used as post hoc tests to determine differences between variable categories. Unpaired two-sample $t$-tests were used to compare differences between the mean study mean for health and clinic EEHVHD elephants. 


\section{Results}

\subsection{Animals}

General health evaluations found eight of the calves were healthy during the study, with no clinical signs of illness observed. Only one elephant (E5, 27-months old) in the non-fatal EEHV group developed signs of EEHV-HD, e.g., diarrhea, depression, lethargy, and facial edema, and died within $72 \mathrm{~h}$ (Table 1). A summary of viral load, hematology values, and stress indicator concentrations of E5 throughout the study is shown in Table 2. This animal had survived an earlier infection with EEHV1A in June 2018 before study onset but was later infected with EEHV1A during the study in June 2019. During the first infection, the animal presented signs of lethargy, depression, and facial edema. This animal was treated with an antiviral drug (famciclovir, Famvir ${ }^{\circledR}$, Novartis Co., Ltd., London, UK) per rectal immediately on the first day clinical signs were observed. On the 3rd day of treatment, clinical signs resolved, although antiviral treatment was continued for 7 days. However, during the second infection, the animal developed severe diarrhea for 2 consecutive days (14 and 15 June 2019) prior to the manifestation of EEHV-HD clinical signs on Day 3 (16 June 2019), and so was transferred to the elephant hospital in Lampang (National Elephant Institute, Forest Industry Organization) for intensive treatment, including administering a different antiviral drug (acyclovir, Vilerm ${ }^{\circledR}$ IV Infusion, Siam Pharmaceutical Co., Ltd., Bangkok, Thailand), plasma therapy, and supportive fluids and multivitamins. This animal did not respond and died on Day 4 (19 June 2019) of treatment in the hospital.

\subsection{Hematological Values}

Hematology results for each elephant throughout the study period are shown in Table 3. Values from eight healthy calves with no clinical illness in the non-EEHV and prior-EEHV groups (i.e., all except E5) were averaged and analyzed across the three seasons in Thailand and within EEHV status with a comparison between the current study and published reference range values (Table 4). Packed-cell volume (PCV), red blood cell count (RBC), monocytes, and monocyte/heterophil (M:H) ratios were highest in the winter compared to the summer and the rainy season. There were no significant differences among the non-EEHV and prior-EEHV elephant groups (Figures 1 and 2, and Supplementary File). In addition, average hematology values of E5 in the 7 months before developing EEHV-HD were in the normal range and did not differ from the other elephants, except for PCV, which was lower compared to the study mean (Figure 3). In E5, marked decreases in WBC counts, lymphocytes, monocytes, and platelets were observed on the first day clinical signs of EEHV-HD appeared and continued until death on Day 3. The lowest PCV and RBC were found on the first day of clinical presentation (1.3 and 1.1 times the study mean, respectively). The lowest monocyte count and $\mathrm{M}: \mathrm{H}$ ratio was found on the second day of clinical presentation (4.9 and 9.6 times, respectively). The lowest lymphocyte and platelet counts were found on the third day of clinical presentation (5.8 and 6.2 times, respectively). The viral load was high on the first day $(6,902,328 \mathrm{vgc} / \mathrm{mL})$ and decreased only slightly during treatment on Day 1 and 2 but surged again on Day 3 (Table 2). 
Table 2. Summary hematology values change, and stress indicators result in an elephant (E5) that developed clinical signs of EEHV-HD and died during the study period.

\begin{tabular}{|c|c|c|c|c|c|c|c|c|c|c|c|}
\hline Parameters & Study Means & $\begin{array}{c}18 \text { December } \\
2018\end{array}$ & $\begin{array}{l}9 \text { January } \\
2019\end{array}$ & $\begin{array}{l}8 \text { February } \\
2019\end{array}$ & 8 March 2019 & 6 April 2019 & 6 May 2019 & 4 June 2019 & 16 June 2019 & 17 June 2019 & 18 June 2019 \\
\hline Viral load (vgc/mL) & - & Undetected & Undetected & Undetected & Undetected & Undetected & Undetected & Undetected & $6,902,328$ & $4,845,925$ & $5,744,321$ \\
\hline PCV (\%) & $37.3 \pm 0.38$ & 30 & 31 & 36 & 33 & 36 & 33 & 32 & 29 & 30 & 31 \\
\hline $\mathrm{RBC}\left(\times 10^{6}\right.$ cells $\left./ \mu \mathrm{L}\right)$ & $3.10 \pm 0.03$ & 2.81 & 2.93 & 3.37 & 3.08 & 3.33 & 3.02 & 2.88 & 2.73 & 3.29 & 2.95 \\
\hline WBC (cells/ $\mu \mathrm{L})$ & $18825 \pm 351$ & 16,230 & 17,760 & 20,640 & 22,300 & 15,370 & 15,010 & 14,140 & 10,110 & 14,300 & 8330 \\
\hline Heterophils (cells $/ \mu \mathrm{L}$ ) & $4247 \pm 136$ & 3246 & 2309 & 7018 & 10,704 & 4765 & 3753 & 3394 & 5561 & 8065 & 5081 \\
\hline Lymphocytes (cells/ $\mu \mathrm{L}$ ) & $10,675 \pm 358$ & 10,063 & 12,077 & 8050 & 9143 & 9222 & 8256 & 7353 & 2325 & 2054 & 1833 \\
\hline Monocytes (cells/ $\mu \mathrm{L})$ & $3459 \pm 219$ & 2434 & 2842 & 5366 & 2230 & 1383 & 3002 & 2969 & 2224 & 700 & 1333 \\
\hline Eosinophile (cells $/ \mu \mathrm{L}$ ) & $296 \pm 28$ & 487 & 532 & 206 & 618 & 0 & 0 & 428 & 143 & 0 & 83 \\
\hline Platelets $\left(\times 10^{3}\right.$ cells $\left./ \mu \mathrm{L}\right)$ & $458 \pm 8$ & 515 & 553 & 802 & 541 & 459 & 580 & 540 & 194 & 98 & 74 \\
\hline $\begin{array}{l}\text { Monocyte/Heterophil } \\
\text { ratio }\end{array}$ & $0.87 \pm 0.05$ & 0.75 & 1.23 & 0.76 & 0.21 & 0.29 & 0.80 & 0.87 & 0.40 & 0.09 & 0.26 \\
\hline Salivary cortisol (ng/mL) & $1.17 \pm 0.08$ & 1.03 & 0.91 & 1.57 & 0.78 & 1.27 & 0.40 & 0.39 & No sample & No sample & No sample \\
\hline FGM (ng/g) & $36.1 \pm 3.19$ & 72.30 & 62.59 & 34.37 & 39.26 & 103.11 & 48.73 & 15.56 & No sample & No sample & No sample \\
\hline $\operatorname{SIgA}(\mu \mathrm{g} / \mathrm{mL})$ & $3.53 \pm 0.31$ & 3.70 & 4.98 & 5.50 & 5.04 & 5.49 & 2.78 & 1.70 & No sample & No sample & No sample \\
\hline
\end{tabular}


Table 3. Mean ( \pm SEM) hematology values of individual elephants in the study.

\begin{tabular}{|c|c|c|c|c|c|c|c|c|c|c|}
\hline \multirow[b]{2}{*}{ Parameter } & \multicolumn{9}{|c|}{ Elephant ID (Blood Sample Number) } & \multirow[b]{2}{*}{ Range } \\
\hline & $\begin{array}{c}\mathrm{E} 1 \\
(n=13)\end{array}$ & $\begin{array}{c}\mathrm{E} 2 \\
(n=13)\end{array}$ & $\begin{array}{c}\text { E3 } \\
(n=13)\end{array}$ & $\begin{array}{c}\mathrm{E} 4 \\
(n=13)\end{array}$ & $\begin{array}{c}\text { E5* } \\
(n=7)\end{array}$ & $\begin{array}{c}\mathrm{E} 6 \\
(n=13)\end{array}$ & $\begin{array}{c}\mathrm{E} 7 \\
(n=13)\end{array}$ & $\begin{array}{c}\mathrm{E} 8 \\
(n=13)\end{array}$ & $\begin{array}{c}\mathrm{E} 9 \\
(n=13)\end{array}$ & \\
\hline PCV $(\%)$ & $\begin{array}{c}42.40 \pm \\
1.08\end{array}$ & $\begin{array}{c}33.50 \pm \\
0.80\end{array}$ & $\begin{array}{c}37.60 \pm \\
1.18\end{array}$ & $\begin{array}{c}36.00 \pm \\
0.30\end{array}$ & $\begin{array}{c}28.90 \pm \\
3.62\end{array}$ & $\begin{array}{c}36.90 \pm \\
0.57\end{array}$ & $\begin{array}{c}35.40 \pm \\
1.11\end{array}$ & $\begin{array}{c}35.70 \pm \\
1.03\end{array}$ & $\begin{array}{c}35.40 \pm \\
1.38\end{array}$ & $32.25-43.80$ \\
\hline $\begin{array}{c}\mathrm{RBC}\left(\times 10^{6}\right. \\
\text { cells } / \mu \mathrm{L})\end{array}$ & $3.37 \pm 0.08$ & $2.84 \pm 0.08$ & $3.10 \pm 0.12$ & $2.88 \pm 0.02$ & $2.68 \pm 0.37$ & $3.00 \pm 0.06$ & $2.93 \pm 0.99$ & $2.95 \pm 0.09$ & $2.89 \pm 0.08$ & $2.17-3.47$ \\
\hline $\begin{array}{c}\text { WBC } \\
\text { (cells } / \mu \mathrm{L} \text { ) }\end{array}$ & $\begin{array}{l}17,731 \pm \\
1245\end{array}$ & $\begin{array}{l}19,700 \pm \\
1236\end{array}$ & $\begin{array}{c}17,979 \pm \\
942\end{array}$ & $\begin{array}{c}16,124 \pm \\
709\end{array}$ & $\begin{array}{l}15,181 \pm \\
4051\end{array}$ & $\begin{array}{l}17,262 \pm \\
\quad 611\end{array}$ & $\begin{array}{c}17,523 \pm \\
489\end{array}$ & $\begin{array}{l}17,165 \pm \\
910\end{array}$ & $\begin{array}{l}18,257 \pm \\
3088\end{array}$ & $\begin{array}{l}14,810- \\
21,990\end{array}$ \\
\hline $\begin{array}{l}\text { Heterophils } \\
\text { (cells/ } / \mathrm{L} \text { ) }\end{array}$ & $\begin{array}{c}5147 \pm \\
1246\end{array}$ & $4467 \pm 303$ & $3687 \pm 384$ & $4629 \pm 500$ & $\begin{array}{c}4300 \pm \\
1421\end{array}$ & $4176 \pm 539$ & $4421 \pm 274$ & $4421 \pm 282$ & $3989 \pm 274$ & $2920-7587$ \\
\hline $\begin{array}{l}\text { Lymphocyte } \\
\text { (cells } / \mu \mathrm{L} \text { ) }\end{array}$ & $\begin{array}{c}10,051 \pm \\
1033\end{array}$ & $\begin{array}{c}11,928 \pm \\
877\end{array}$ & $\begin{array}{c}10,633 \pm \\
751\end{array}$ & $7982 \pm 956$ & $8020 \pm 181$ & $8725 \pm 813$ & $9698 \pm 301$ & $9367 \pm 569$ & $\begin{array}{l}10,706 \pm \\
1865\end{array}$ & $\begin{array}{r}6918- \\
13,980\end{array}$ \\
\hline $\begin{array}{l}\text { Monocytes } \\
(\text { cells } / \mu \mathrm{L} \text { ) }\end{array}$ & $3059 \pm 192$ & $3817 \pm 892$ & $3176 \pm 153$ & $3298 \pm 678$ & $2528 \pm 690$ & $3175 \pm 143$ & $3176 \pm 333$ & $3167 \pm 342$ & $3111 \pm 352$ & $2316-5578$ \\
\hline $\begin{array}{l}\text { Eosinophils } \\
\text { (cells } / \mu \mathrm{L})\end{array}$ & $374 \pm 80$ & $321 \pm 53$ & $265 \pm 33$ & $143 \pm 96$ & $2234 \pm 128$ & $413 \pm 50$ & $282 \pm 37$ & $276 \pm 35$ & $208 \pm 35$ & $0-535$ \\
\hline $\begin{array}{l}\text { Platelets } \\
\left(\times 10^{3}\right. \\
\text { cells } / \mu \mathrm{L})\end{array}$ & $552 \pm 23$ & $465 \pm 14$ & $464 \pm 18$ & $463 \pm 20$ & $499 \pm 104$ & $424 \pm 39$ & $466 \pm 15$ & $465 \pm 18$ & $416 \pm 8$ & $374-554$ \\
\hline M:H ratio & $0.66 \pm 0.16$ & $0.84 \pm 0.13$ & $0.90 \pm 0.14$ & $0.74 \pm 0.17$ & $0.58 \pm 0.03$ & $0.77 \pm 0.07$ & $0.72 \pm 0.05$ & $0.74 \pm 0.05$ & $0.78 \pm 0.13$ & $0.41-1.17$ \\
\hline
\end{tabular}

Table 4. Mean $( \pm S E M)$ hematology values and stress indicator concentrations in eight young calves without clinical illness throughout the study period, excluding E5 that developed EEHV-HD and died during the study.

\begin{tabular}{|c|c|c|c|c|c|}
\hline \multirow{2}{*}{ Variables } & \multirow{2}{*}{$\begin{array}{c}\text { Mean Value in } \\
\text { the Study } \\
(n=104)\end{array}$} & \multirow{2}{*}{ Range } & \multirow{2}{*}{ Fowler et al. (2006) } & \multicolumn{2}{|c|}{ Janyamethakul et al. (2017) } \\
\hline & & & & Male & Female \\
\hline PCV (\%) & $37.3 \pm 0.38$ & $32.25-43.80$ & $30-40$ & $29.40-40.70$ & $27.80-43.00$ \\
\hline $\mathrm{RBC}\left(\times 10^{6}\right.$ cells $\left./ \mu \mathrm{L}\right)$ & $3.10 \pm 0.03$ & $2.17-3.47$ & $2.00-5.00$ & $1.90-3.20$ & $1.90-3.10$ \\
\hline WBC (cells/ $\mu \mathrm{L})$ & $18,825 \pm 351$ & $14,810-21,990$ & $10,000-18,000$ & $7924-21,890$ & $7202.50-23,220.50$ \\
\hline Heterophils (cells $/ \mu \mathrm{L}$ ) & $4247 \pm 136$ & $2920-7587$ & $2000-4000$ & $967-13426$ & $828.70-13,514.30$ \\
\hline Lymphocytes (cells/ $\mu \mathrm{L}$ ) & $10,675 \pm 358$ & $6918-13,980$ & $5000-8000$ & $1672-11,179$ & $1064.10-12,032.80$ \\
\hline Monocytes (cells $/ \mu \mathrm{L})$ & $3459 \pm 219$ & $2316-5578$ & $2000-4000$ & $0-2391$ & $0-3298$ \\
\hline Eosinophils (cells $/ \mu \mathrm{L}$ ) & $296 \pm 28$ & $0-535$ & $100-1000$ & $0-867$ & $0-1170$ \\
\hline Platelets $\left(\times 10^{3}\right.$ cells $\left./ \mu \mathrm{L}\right)$ & $458 \pm 8.38$ & $374-554$ & $200-600$ & $102-578$ & $105.30-598.70$ \\
\hline Monocyte/Heterophil ratio & $0.87 \pm 0.05$ & $0.41-1.17$ & $1.18-3.57$ & ND & ND \\
\hline Salivary cortisol (ng/mL) & $1.17 \pm 0.08$ & $0.65-1.95$ & ND & ND & ND \\
\hline FGM (ng/mL) & $36.1 \pm 3.19$ & $23.55-53.51$ & ND & ND & ND \\
\hline $\operatorname{SIgA}(\mu \mathrm{g} / \mathrm{mL})$ & $3.53 \pm 0.31$ & $1.28-12.60$ & ND & ND & ND \\
\hline $\operatorname{FIgA}(\mu \mathrm{g} / \mathrm{mL})$ & $1.85 \pm 0.10$ & 1.339 .04 & ND & ND & ND \\
\hline
\end{tabular}




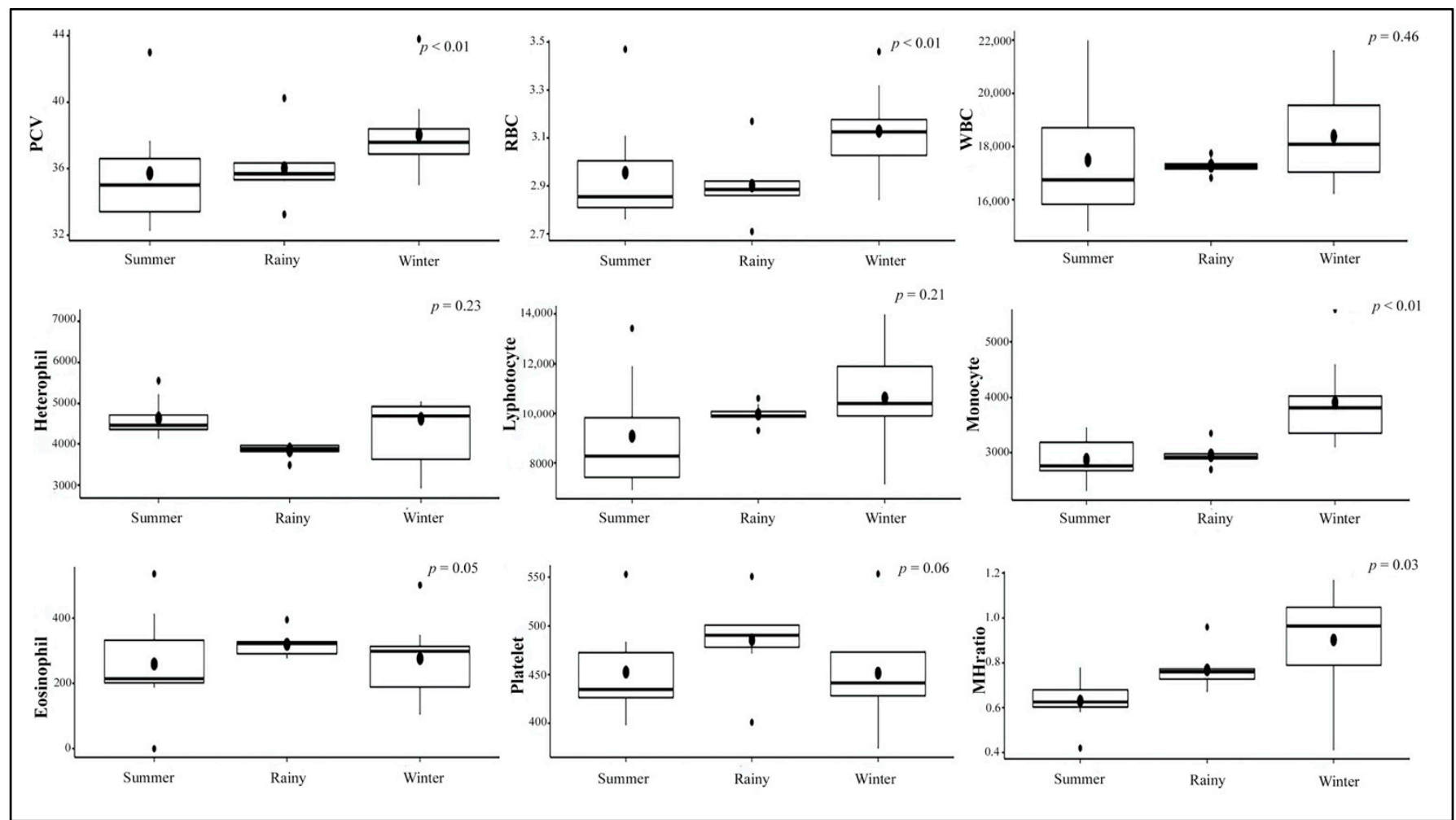

Figure 1. Boxplots of hematology values across three seasons in Thailand, excluding E5 that developed EEHV-HD and died during the study.
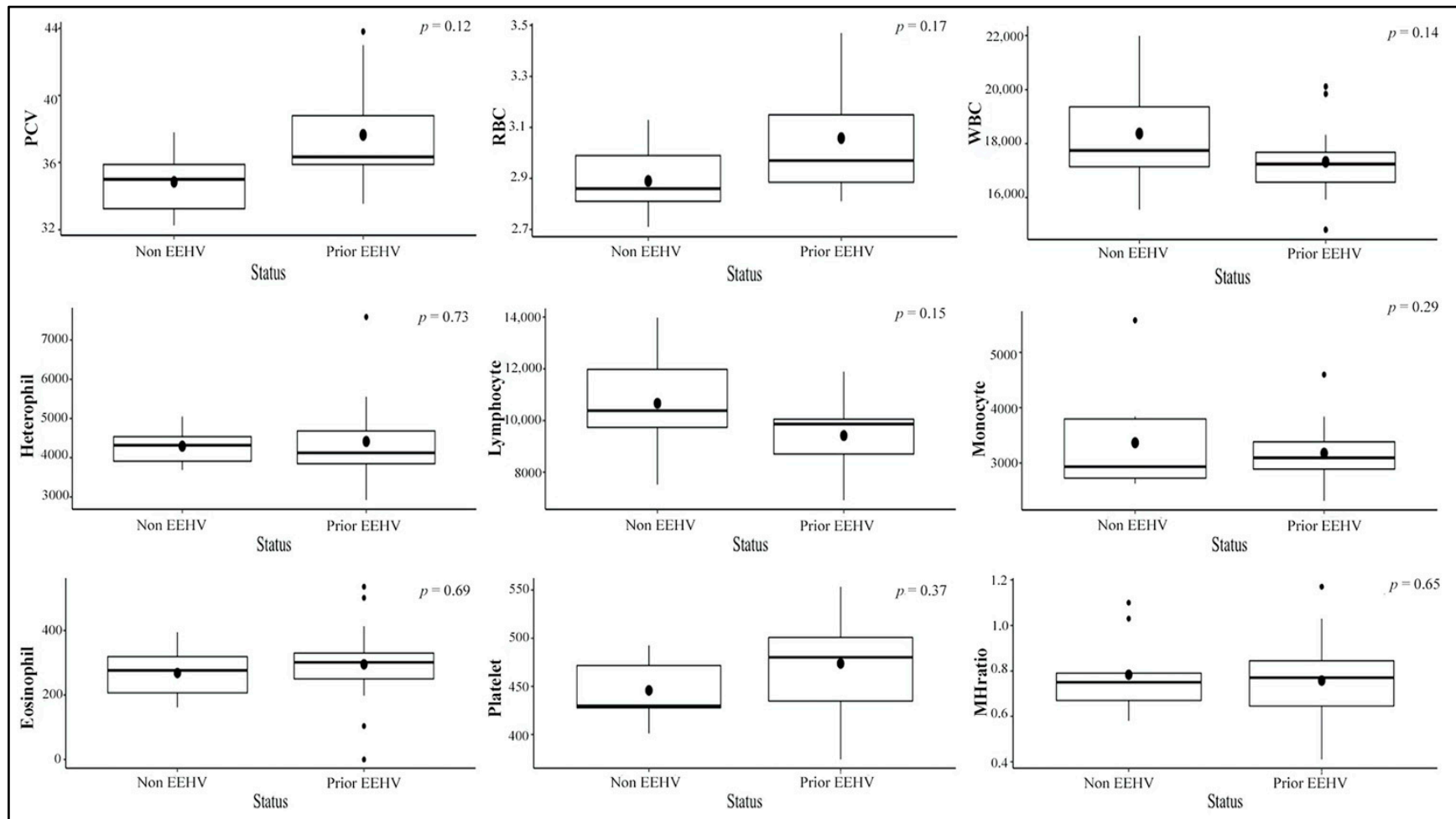

Figure 2. Boxplots of hematology values according to EEHV status (non-EEHV or prior-EEHV), excluding E5 that developed EEHV-HD and died during the study. 


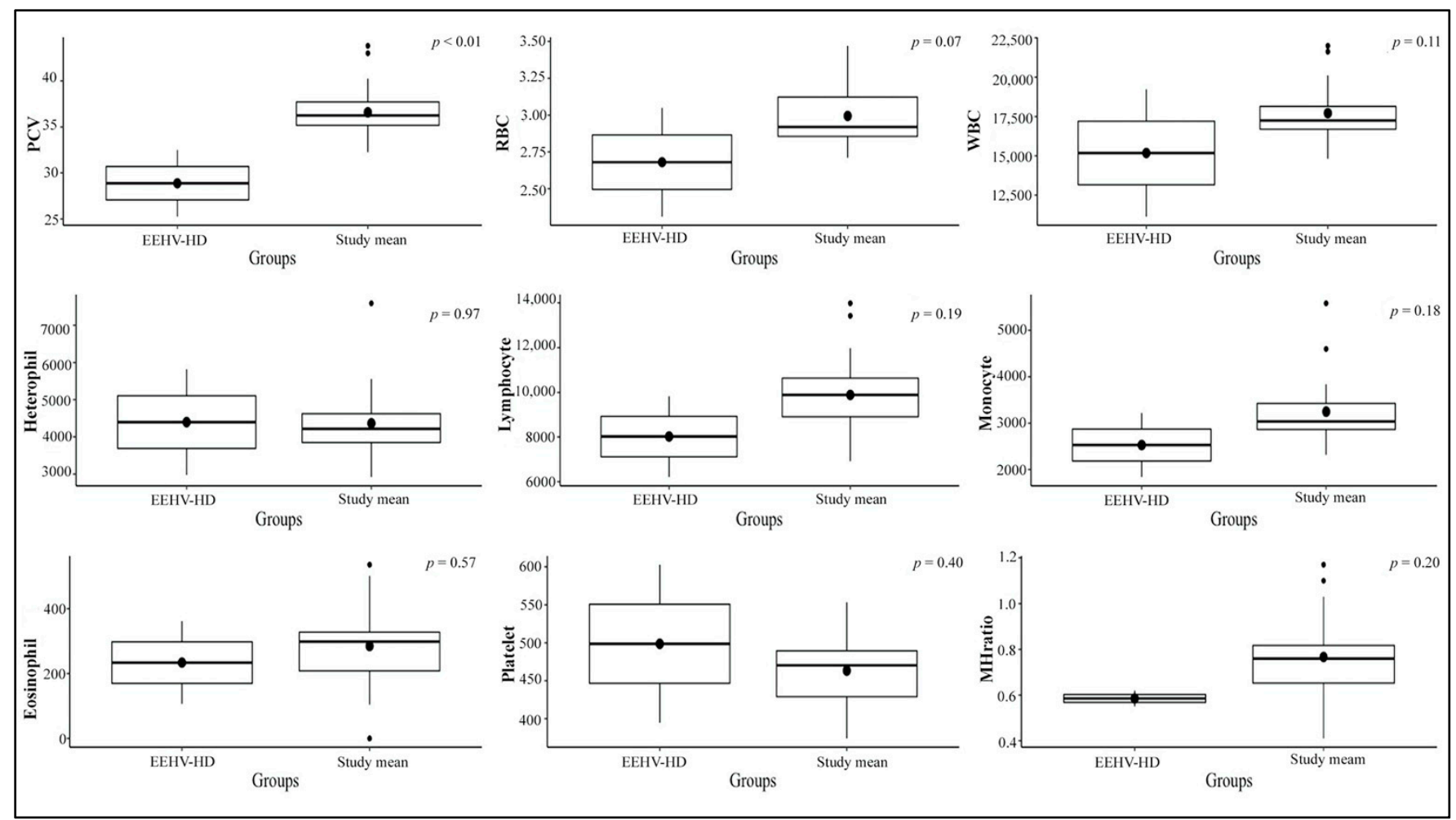

Figure 3. Boxplot presented significant differences in hematology between EEHV-HD and the study mean.

\subsection{Stress Indicator Concentrations}

Overall mean concentrations of glucocorticoids and IgA for individuals during the study are shown in Table 5. Salivary cortisol concentrations were higher in the winter than the rainy and the summer, whereas FGM concentrations were higher in the summer than the rainy and the winter. SIgA concentrations in the rainy season were higher than those in the winter and the summer, whereas FIgA concentrations in the summer were higher than those in the winter and the rainy seasons (Figure 4). Salivary cortisol in the non-EEHV was lower than the prior EEHV groups significantly different. There were no differences in FGM, SIgA, or FIgA concentrations between the non-EEHV and prior-EEHV groups (Figure 5). In E5, fluctuations in SC, FGM, SIgA, and FIgA were observed during the 7 months of sample collection, with no significant differences compared to the normal range (Figure 6). However, in June 2019, the last month of sample collection, concentrations of SC, FGM, SIgA, and FIgA were all lower than the study mean and also the overall mean for that individual (Table 2). 
Table 5. Overall mean $( \pm \mathrm{SEM})$ concentrations of salivary cortisol, fecal glucocorticoid metabolites (FGM), salivary IgA (SIgA), and fecal $\operatorname{Ig} \mathrm{A}(\mathrm{FIgA})$ in individual elephants in the study.

\begin{tabular}{|c|c|c|c|c|c|c|c|c|c|c|}
\hline \multirow[b]{2}{*}{ Variable } & \multicolumn{9}{|c|}{ Elephant ID } & \multirow[b]{2}{*}{ Range } \\
\hline & $\begin{array}{c}\text { E1 } \\
(n=12)\end{array}$ & $\begin{array}{c}\mathrm{E} 2 \\
(n=12)\end{array}$ & $\begin{array}{c}\text { E3 } \\
(n=12)\end{array}$ & $\begin{array}{c}\mathrm{E} 4 \\
(n=12)\end{array}$ & $\begin{array}{c}\text { E5 * } \\
(n=7)\end{array}$ & $\begin{array}{c}\mathrm{E} 6 \\
(n=12)\end{array}$ & $\begin{array}{c}\text { E7 } \\
(n=12)\end{array}$ & $\begin{array}{c}\mathrm{E} 8 \\
(n=12)\end{array}$ & $\begin{array}{c}\text { E9 } \\
(n=12)\end{array}$ & \\
\hline $\begin{array}{c}\text { Salivary } \\
\text { cortisol } \\
(\mathrm{ng} / \mathrm{mL})\end{array}$ & $\begin{array}{c}1.40 \pm \\
0.18\end{array}$ & $\begin{array}{c}0.72 \pm \\
0.04\end{array}$ & $\begin{array}{c}0.97 \pm \\
0.02\end{array}$ & $\begin{array}{c}1.40 \pm \\
0.30\end{array}$ & $\begin{array}{c}0.75 \pm \\
0.32\end{array}$ & $\begin{array}{c}1.33 \pm \\
0.21\end{array}$ & $\begin{array}{c}1.06 \pm \\
0.13\end{array}$ & $\begin{array}{c}1.10 \pm \\
0.12\end{array}$ & $\begin{array}{c}0.90 \pm \\
0.01\end{array}$ & $\begin{array}{l}0.65- \\
1.95\end{array}$ \\
\hline $\begin{array}{c}\text { FGM } \\
(\mathrm{ng} / \mathrm{mL})\end{array}$ & $\begin{array}{c}31.3 \pm \\
4.14\end{array}$ & $\begin{array}{c}36.10 \pm \\
5.02\end{array}$ & $\begin{array}{c}36.00 \pm \\
4.85\end{array}$ & $\begin{array}{c}39.8 \pm \\
5.83\end{array}$ & $\begin{array}{c}47.00 \pm \\
5.14\end{array}$ & $\begin{array}{c}32.00 \pm \\
4.10\end{array}$ & $\begin{array}{c}36.70 \pm \\
3.72\end{array}$ & $\begin{array}{c}37.00 \pm \\
3.47\end{array}$ & $\begin{array}{c}40.90 \pm \\
8.21\end{array}$ & $\begin{array}{l}23.55- \\
53.51\end{array}$ \\
\hline $\begin{array}{c}\mathrm{SIgA} \\
(\mu \mathrm{g} / \mathrm{mL})\end{array}$ & $\begin{array}{c}2.63 \pm \\
0.66\end{array}$ & $\begin{array}{c}7.85 \pm \\
293\end{array}$ & $\begin{array}{c}4.66 \pm \\
1.18\end{array}$ & $\begin{array}{c}4.328 \pm \\
1.70\end{array}$ & $\begin{array}{c}3.66 \pm \\
1.15\end{array}$ & $\begin{array}{c}4.33 \pm \\
184\end{array}$ & $\begin{array}{c}5.14 \pm \\
1.75\end{array}$ & $\begin{array}{c}4.72 \pm \\
1.45\end{array}$ & $\begin{array}{c}3.91 \pm \\
0.61\end{array}$ & $\begin{array}{l}1.28- \\
12.60\end{array}$ \\
\hline $\begin{array}{c}\text { FIgA } \\
(\mu \mathrm{g} / \mathrm{mL})\end{array}$ & $\begin{array}{c}2.43 \pm \\
0.38\end{array}$ & $\begin{array}{c}5.00 \pm \\
2.23\end{array}$ & $\begin{array}{c}3.38 \pm \\
1.08\end{array}$ & $\begin{array}{c}2.46 \pm \\
0.55\end{array}$ & $\begin{array}{c}4.38 \pm \\
1.75\end{array}$ & $\begin{array}{c}2.16 \pm \\
0.15\end{array}$ & $\begin{array}{c}3.23 \pm \\
0.80\end{array}$ & $\begin{array}{c}2.97 \pm \\
0.53\end{array}$ & $\begin{array}{c}3.18 \pm \\
0.74\end{array}$ & $\begin{array}{l}1.33- \\
9.04\end{array}$ \\
\hline
\end{tabular}

${ }^{*}$ Developed EEHV-HD and died before the end of sample collection.

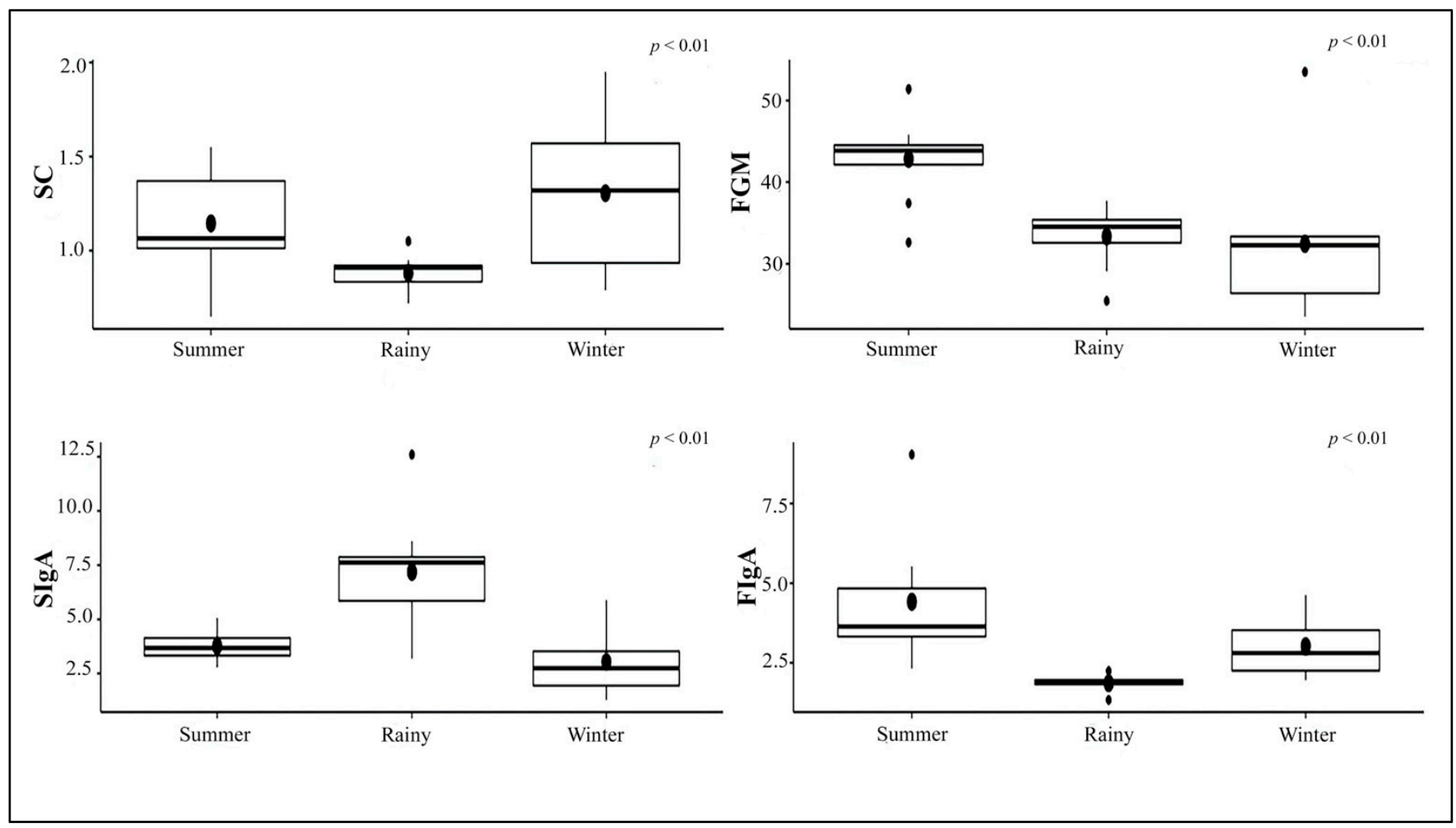

Figure 4. Boxplot presented concentrations of salivary cortisol (SC), fecal glucocorticoid metabolites (FGM), salivary IgA (SIgA), and fecal $\operatorname{Ig} \mathrm{A}(\mathrm{FIgA})$ categorized by season. 

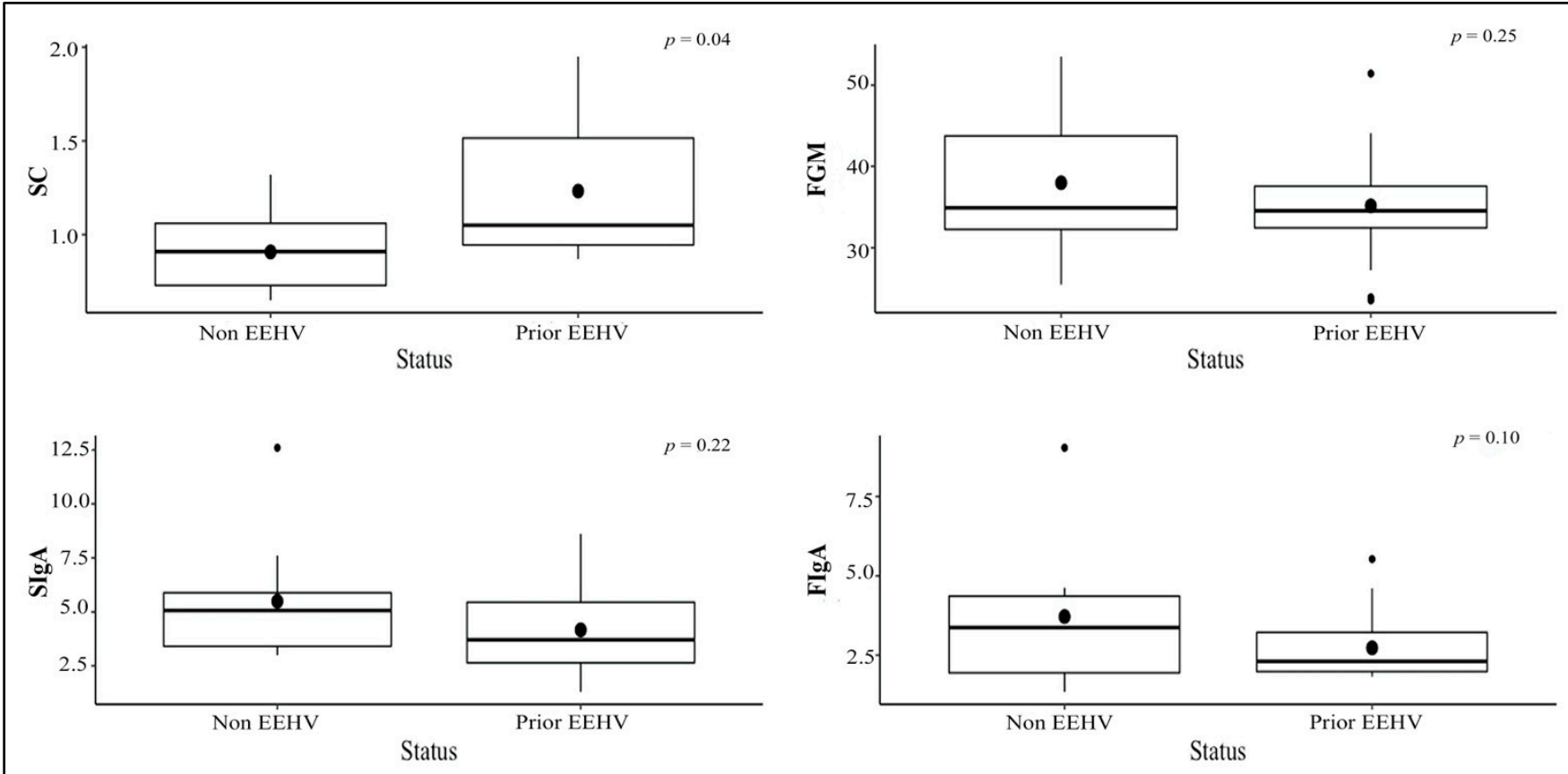

Figure 5. Boxplot presented concentrations of salivary cortisol (SC), fecal glucocorticoid metabolites (FGM), salivary IgA (SIgA), and fecal IgA (FIgA) categorized by EEHV status (non-EEHV or prior-EEHV), excluding E5 that developed EEHV-HD and died during the study.

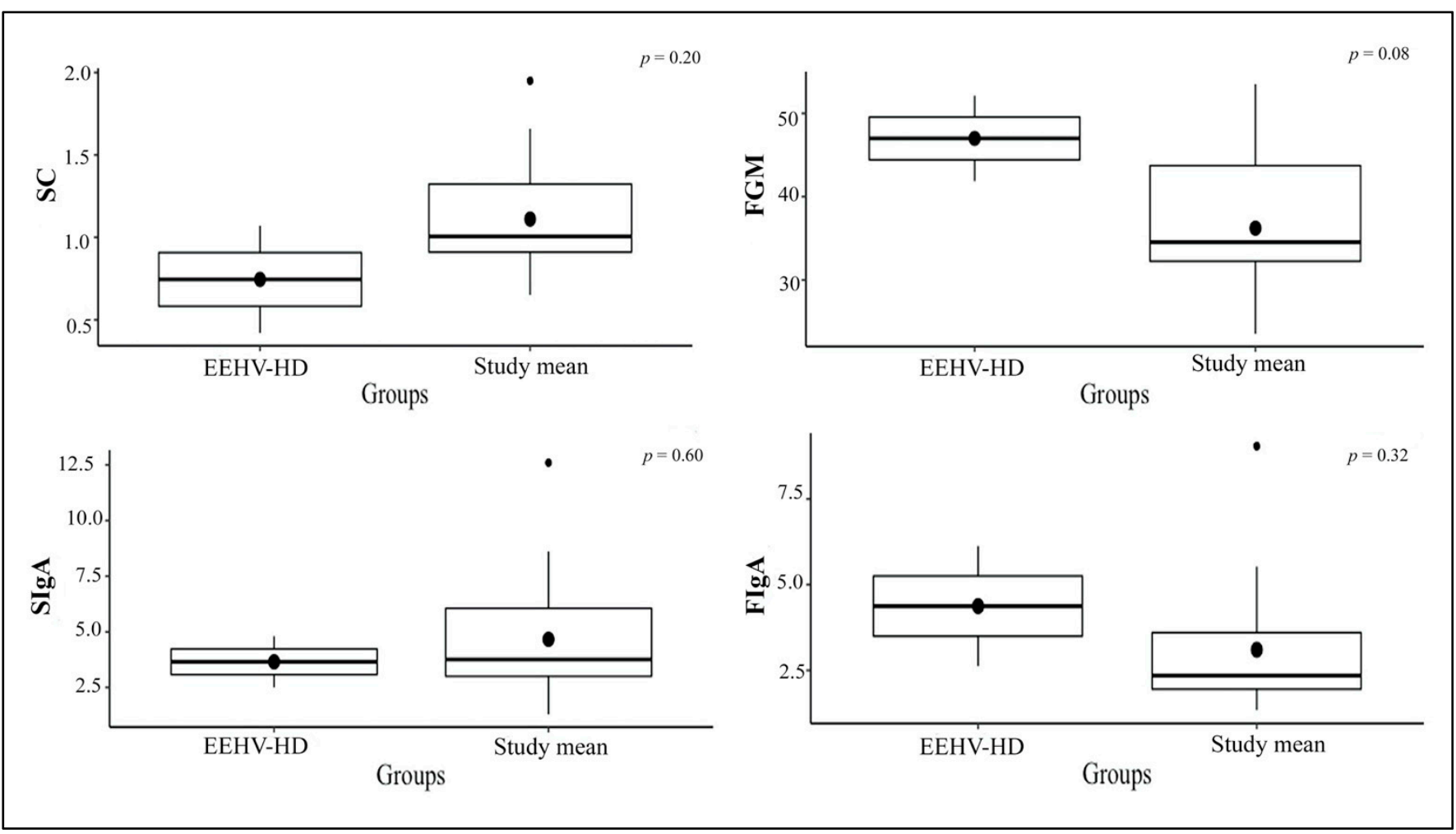

Figure 6. Boxplot presented significant differences in biological indicators between EEHV-HD and study mean. 


\subsection{Viremia Monitoring}

Over the 12-month period, viremia was detected in two elephants (E3 and E5). For E3, low viremia $(137 \mathrm{vgc} / \mathrm{mL})$ was observed only once in the first month of sample collection without clinical signs of EEHV-HD, whereas a high viral load $(6,902,328 \mathrm{vgc} / \mathrm{mL})$ and EEHV-HD clinical signs were detected in E5 in the seventh month of sample collection (Table 2). Other elephants in the non-EEHV infection (E2, E8, and E9) and prior-EEHV (E1, E4, E6, and E7) groups did not show any clinical illness or EEHV viremia during the study.

\section{Discussion}

This is the first study to monitor longitudinal hematology and stress biomarkers (glucocorticoids and IgA) in saliva and feces in relation to EEHV status in Asian elephant calves. Results document normal range values of hematology and stress biomarkers in elephant calves, the age most at risk for developing EEHV-HD [5,16,17,51]. These normal range values can have predictive value for rapid diagnosis of early EEHV infection and improving survival outcomes [2]. In the one calf that was re-infected and died of HD, there were expected changes in hematology, but also decreases in stress-response measures, preliminarily suggesting they may also be informative and deserve further attention.

There was a seasonal effect on hematology values (PCV, RBC, monocytes, and M:H ratio) and welfare indicators in this study. Higher PCV and RBC have been observed in humans [52,53] and horses [54] during the winter in association with dehydration, although there was no indication that the healthy calves in this study experienced a lack of water. Monocytes and the $\mathrm{M}: \mathrm{H}$ ratio were higher in the winter compared to the other two seasons. In humans, high WBC and monocytes in the winter could be a defense mechanism against infectious diseases [55] or associated with cold stress [56]. By contrast, in cattle, WBC and monocytes were higher in the summer season due to the release of corticosteroids or epinephrine as a result of relatively higher temperatures, which in turn increased leukocyte counts $[57,58]$. More work is needed to understand these seasonal effects and how they relate to health status.

Several studies have examined FGM and SIgA as welfare indicators to understand how tourist activities affect the quality of life of elephants in Thailand [34,42,44,59]. In this study, these techniques were used to determine how stress responses might be associated with compromised host immunity and the consequent development of EEHV-HD in young calves. However, only two elephants exhibited any viremia during the study. In one case, the viral load was low and not indicative of $\mathrm{HD}$, and there were no changes in stress biomarker concentrations. The other elephant did develop HD and died within a few days. Concentrations of all biomarkers were markedly lower in the fecal and saliva samples collected 12 days before viremia was detected. No fecal or salivary samples were collected closer to or during the time clinical signs were observed, so the degree of these changes might have been even greater. A form of hypoadrenalism might have been at play in this calf, similar to a study in zoo black rhinoceros where reduced concentrations of FGM were found in association with the manifestation of severe skin disease [60]. As an important immune biomarker related to health status in humans and animals, decreases in IgA concentrations also have been related to chronic disease [46]. In dogs, significantly decreased concentrations of FIgA were found to be associated with inflammatory bowel disease [61]. In elephants, salivary IgA concentrations are lower in the summer, the season with the highest prevalence of gastrointestinal tract illnesses [42]. In E5, intermittent mild diarrhea was observed along with other EEHV clinical signs, so more studies to assess changing patterns of glucocorticoids and IgA associated with EEHV-HD cases are warranted.

Seasonal effects on stress indicators were found in this study, although not always in the same direction. A previous study of tourist elephants found salivary cortisol concentrations varied across environmental seasons, being high in the winter, intermediate in the summer, and lowest in the rainy season [42], similar to this study. In other species, such as pigs [62] and red deer [63], circulating glucocorticoid concentrations increased in 
response to cold stress. Additionally, the winter is the high tourist season in Thailand, when elephants have more activities $[59,64]$ and are fed higher energy foods by tourists [42]. Therefore, high energy intake and energy demand for maintaining body temperature in cooler months might increase cortisol in blood circulation [64] followed by increases in saliva as noted in this study. Other studies in Asian elephants found FGM concentrations were highest in the winter in Spain [33] and during the logging season (June-August) in semi-captive elephants in Myanmar [65], while there were no seasonal differences in FGM concentrations in zoo elephants in the U.S. [66]. In this study, the highest FGM concentrations were found in the summer and so differed from our previous studies in adult elephants $[42,59,64]$. Calves often interact with tourists, but in this age group, the high tourist season was not associated with increases in adrenal activity. Temperatures are high during the summer in the northern part of Thailand (range, 36-42 ${ }^{\circ} \mathrm{C}$ ) (www.tmd.go.th, accessed on 12 July 2020) and so might be related to physiological responses to thermal stress similar to that described for cattle $[67,68]$ and sheep [69]. Moreover, variation in FGM concentrations can result from factors such as gender, diet, age, reproductive status, and habitat [70], and so should be considered in further studies of young calves.

In the previous study, SIgA concentrations were highest in the winter and high tourist season in adult elephants [42]. In this study, higher SIgA was found in the rainy season, which might be related to health status. In the rainy season, elephants generally have access to better quality food, which might result in good body condition scores and immunity. Future studies should monitor elephant body condition and health parameters in addition to stress biomarkers in older and younger age categories. The FIgA results also varied between young and adult elephants. In the previous study, FIgA excretion was consistent throughout the year in adult elephants [42], unlike this study where the highest FIgA concentrations were observed in the summer in young calves. Variations in FIgA concentration have been associated with factors such as a stressor (decrease), an acute illness (increase), and positive stimuli (increase) [46]. Thus, interpretation of FIgA as a stress biomarker needs to be done in consideration of other factors such as age, health status, and management in individual animals.

These findings confirm that animals that survive EEHV1A infection can be re-infected with the same viral subtype. The calf was viremic a year before the study and died soon after developing clinical signs during re-infection. One other study reported EEHV re-infection, but that involved two different types-EEHV1B followed by EEHV4 [11]. This phenomenon could be explained by the reactivation of latent viruses from the first infection [11]. In this calf, the severity of clinical signs in the primary infection was categorized as Level 4 [5], while the secondary infection was Level 5, the highest category indicating a serious infection [5]. Differences in severity of clinical signs might be prognostic of survival outcomes, but there is little empirical evidence of that to date.

Changes in hematology values, particularly WBC parameters, were associated with EEHV1A viremia in the calf that developed HD and died. The calf displayed lymphocytopenia, monocytopenia, and thrombocytopenia, which have been described in other reports $[2,4,11,12]$. Generally, hematology profiles are an important indicator of physiological changes in animals [71,72]. Monitoring the $\mathrm{M}: \mathrm{H}$ ratio has been suggested to be another indicator of clinical EEHV progression, with a decrease associated with disease [2]. In the calf that died, the average $\mathrm{M}: \mathrm{H}$ was low during the presentation of clinical signs compared with the study mean in this and another study [2]. Moreover, PVC, RBC, lymphocytes, monocytes, platelets, and the $\mathrm{M}: \mathrm{H}$ ratio also were lower than normal, which is similar to other studies $[2,4,11,12]$ and thus appear to be an important factor to monitor. Glucocorticoid and IgA concentrations in this calf in the 12 days prior to viremia also were markedly lower, about a half or more of those observed in the months prior to viremia, and in comparison, to the other elephants. While these data are very preliminary $(n=1)$, in addition to hematology, it might also be informative to assess stress-related biomarkers in addition to molecular-based PCR analysis to monitor EEHV status, allowing more timely treatment to improve survival outcomes. 
The limitations of this study were the lack of EEHV-HD cases (only one) and the limited frequency of sampling to observe changes in the patterns of glucocorticoids or $\operatorname{IgA}$ in association with viremia during clinical signs. In clinical cases, saliva, feces, and blood should be collected daily to evaluate the correlation and consistency of all parameters when either clinical signs or viremia is detected. Longitudinal saliva and fecal sampling in more calves before, during, and after clinical EEHV presentation are required to fully understand any associations between stress and EEHV-HD.

\section{Conclusions}

This is the first longitudinal study that compared hematology values between nonEEHV and prior-EEHV infected groups and confirmed in the one calf that developed HD and died that changes in hematology parameters such as PCV, lymphocytes, monocytes, and platelets are indicators of clinical EEHV and a useful diagnostic tool before molecular confirmation. Analyses of several stress biomarkers revealed no differences in calves that had tested positive for EEHV-HD but survived compared to healthy controls. However, all biomarkers showed a marked decrease in samples collected 12 days prior to clinical signs in one calf that developed HD and died within $72 \mathrm{~h}$. Although those data are very preliminary with an $n=1$, analyses of stress factors might also provide early warning signs of EEHV viremia and so warrant further investigation. Through the longitudinal study, we found season had an effect on the concentrations of these indicators and so it is important to consider that when interpreting results in individual elephants.

Supplementary Materials: The following are available online at https: / www.mdpi.com/article / 10.3390/ani11092530/s1, Table S1: Hematology and stress indicator concentration of individual elephants.

Author Contributions: Conceptualization, K.B., C.T., V.P. and C.S.; methodology, K.B., Y.Y., P.T. (Patcharapa Towiboon), T.J., P.M., P.T. (Pallop Tankaew), W.K. and C.S.; software, V.P.; validation, K.B., J.L.B., C.T. and C.S.; formal analysis, K.B., V.P. and C.S.; investigation, K.B., Y.Y. and C.S.; resources, C.T.; data curation, K.B. and V.P.; writing-original draft preparation, K.B.; writingreview and editing, K.B., C.T. and J.L.B.; visualization, K.B., W.K. and V.P.; supervision, C.T., J.L.B. and C.S.; project administration, K.B. and C.S.; funding acquisition, C.T. All authors have read and agreed to the published version of the manuscript.

Funding: This study was partially supported by Chiang Mai University.

Institutional Review Board Statement: The study was conducted according to the guidelines of the Declaration of Helsinki, and approved by the Institutional Animal Care and Use Committee, Faculty of Veterinary Medicine, Chiang Mai University, Chiang Mai, Thailand (reference number S2/2562, date of approval: 18 January 2019).

Informed Consent Statement: Not applicable.

Data Availability Statement: The data presented in this study are available on request from corresponding author.

Acknowledgments: We would like to acknowledge elephant camps in Chiang Mai province, Thailand for kind cooperation and supports. A special thanks to Sarisa Klinhom and Siripat Khammesri for assisting in sample collection.

Conflicts of Interest: The authors declare no conflict of interest.

\section{References}

1. Bennett, L.; Dunham, S.; Yon, L.; Chapman, S.; Kenaghan, M.; Purdie, L.; Tarlinton, R. Longitudinal study of Asian elephants, Elephas Maximus, indicates intermittent shedding of elephant endotheliotropic herpesvirus 1 during pregnancy. Vet. Rec. Open 2015, 2, e000088. [CrossRef]

2. Wissink-Argilaga, N.; Dastjerdi, A.; Molenaar, F.M. Using in-house hematology to direct decision making in the successful treatment and monitoring of a clinical and subsequently subclinical case of elephant endotheliotropic herpesvirus 1B. J. Zoo Wildl. Med. 2019, 50, 498-502. [CrossRef] 
3. Garner, M.M.; Helmick, K.; Ochsenreiter, J.; Richman, L.K.; Latimer, E.; Wise, A.G.; Maes, R.K.; Kiupel, M.; Nordhausen, R.W.; Zong, J.C.; et al. Clinico-pathologic features of fatal disease attributed to new variants of endotheliotropic herpesviruses in two Asian elephants (Elephas maximus). Vet. Pathol. 2009, 46, 97-104. [CrossRef] [PubMed]

4. Dastjerdi, A.; Seilern-Moy, K.; Darpel, K.; Steinbach, F.; Molenaar, F. Surviving and fatal elephant endotheliotropic herpesvirus-1A infections in juvenile Asian elephants-Lessons learned and recommendations on anti-herpesviral therapy. BMC Vet. Res. 2016, 12, 178. [CrossRef]

5. Boonprasert, K.; Punyapornwithaya, V.; Tankaew, P.; Angkawanish, T.; Sriphiboon, S.; Titharam, C.; Brown, J.L.; Somgird, C. Survival analysis of confirmed elephant endotheliotropic herpes virus cases in Thailand from 2006-2018. PLoS ONE 2019, 14, e0219288. [CrossRef]

6. Latimer, E.; Zong, J.C.; Heaggans, S.Y.; Richman, L.K.; Hayward, G.S. Detection and evaluation of novel herpesviruses in routine and pathological samples from Asian and African elephants: Identification of two new probosciviruses (EEHV5 and EEHV6) and two new gammaherpesviruses (EGHV3B and EGHV5). Vet. Microbiol. 2011, 147, 28-41. [CrossRef]

7. Abegglen, L.M.; Fuery, A.; Kiso, W.K.; Schmitt, D.L.; Ling, P.D.; Schiffman, J.D. Mammalia: Proboscidea: Elephant Immune System. In Advances in Comparative Immunology; Cooper, E.L., Ed.; Springer International Publishing: Cham, Switzerland, 2018; pp. 863-883. ISBN 978-3-319-76768-0.

8. $\quad$ Atkins, L.; Zong, J.C.; Tan, J.; Mejia, A.; Heaggans, S.Y.; Nofs, S.A.; Stanton, J.J.; Flanagan, J.P.; Howard, L.; Latimer, E.; et al. Elephant endotheliotropic herpesvirus 5, a newly recognized elephant herpesvirus associated with clinical and subclinical infections in captive Asian elephants (Elephas maximus). J. Zoo Wildl. Med. 2013, 44, 136-143. [CrossRef] [PubMed]

9. Stanton, J.J.; Zong, J.C.; Eng, C.; Howard, L.; Flanagan, J.; Stevens, M.; Schmitt, D.; Wiedner, E.; Graham, D.; Junge, R.E.; et al. Kinetics of viral loads and genotypic analysis of elephant endotheliotropic herpesvirus-1 infection in captive Asian elephant (Elephas maximus). J. Zoo Wildl. Med. Off. Publ. Am. Assoc. Zoo Vet. 2013, 44, 42-54. [CrossRef]

10. Richman, L.K.; Montali, R.J.; Cambre, R.C.; Schmitt, D.; Hardy, D.; Hildbrandt, T.; Bengis, R.G.; Hamzeh, F.M.; Shahkolahi, A.; Hayward, G.S. Clinical and pathological findings of a newly recognized disease of elephants caused by endotheliotropic herpesviruses. J. Wildl. Dis. 2000, 36, 1-12. [CrossRef] [PubMed]

11. Fuery, A.; Tan, J.; Peng, R.; Flanagan, J.P.; Tocidlowski, M.E.; Howard, L.L.; Ling, P.D. Clinical infection of two captive Asian elephants (Elephas maximus) with elephant endotheliotropic herpesvirus 1b. J. Zoo Wildl. Med. 2016, 47, 319-324. [CrossRef] [PubMed]

12. Fuery, A.; Browning, G.R.; Tan, J.; Long, S.; Hayward, G.S.; Cox, S.K.; Flanagan, J.P.; Tocidlowski, M.E.; Howard, L.L.; Ling, P.D. Clinical infection of captive Asian elephants (Elephas maximus) with elephant endotheliotropic herpesvirus 4. J. Zoo Wildl. Med. 2016, 47, 311-318. [CrossRef]

13. Howard, L.L.; Schaftenaar, W. 95-Elephant Endotheliotropic Herpesvirus. In Fowler's Zoo and Wild Animal Medicine Current Therapy; Miller, R.E., Lamberski, N., Calle, P.P., Eds.; W.B. Saunders: Philadelphia, PA, USA, 2019; Volume 9, pp. 672-679. ISBN 978-0-323-55228-8.

14. Hengtrakul, P.; Sudlapa, P.; Chaisurat, N.; Sodsaengthien, S.; Chamnankij, C.; Noimoon, S.; Punkong, C.; Phatthanakunanan, S.; Lertwatcharasarakul, P.; Sripiboon, S. Biological and environmental factors associated with the detection of elephant endotheliotropic herpesvirus in Asian elephants (Elephas maximus) in Thailand. J. Vet. Med. Sci. 2020, 82, 1808-1815. [CrossRef] [PubMed]

15. Fowler, M.E.; Mikota, S.K.; Hedges, S. Biology, Medicine, and Surgery of Elephants, 1st ed.; Blackwell Publishing Ltd.: Iowa, IA, USA, 2006; pp. 325-345.

16. Janyamethakul, T.; Sripiboon, S.; Somgird, C.; Pongsopawijit, P.; Panyapornwithaya, V.; Klinhom, S.; Loythong, J.; Thitaram, C. Hematologic and biochemical reference intervals for captive Asian elephants (Elephas maximus) in Thailand. Kafkas Univ. Vet. Fak. Derg. 2017, 23, 665-669. [CrossRef]

17. Perrin, K.L.; Kristensen, A.T.; Gray, C.; Nielsen, S.S.; Bertelsen, M.F.; Kjelgaard-Hansen, M. Biological variation of hematology and biochemistry parameters for the Asian elephant (Elephas maximus), and applicability of population derived reference intervals. J. Zoo Wildl. Med. 2020, 51, 643-651. [CrossRef] [PubMed]

18. Schaftenaar, W.; Reid, C.; Martina, B.; Fickel, J.; Osterhaus, A.D. Nonfatal clinical presentation of elephant endotheliotropic herpes virus discovered in a group of captive Asian elephants (Elephas maximus). J. Zoo Wildl. Med. 2010, 41, 626-632. [CrossRef] [PubMed]

19. Hardman, K.; Dastjerdi, A.; Gurrala, R.; Routh, A.; Banks, M.; Steinbach, F.; Bouts, T. Detection of elephant endotheliotropic herpesvirus type 1 in asymptomatic elephants using TaqMan real-time PCR. Vet. Rec. 2012, 170, 205. [CrossRef]

20. Sripiboon, S.; Tankaew, P.; Lungka, G.; Thitaram, C. The occurrence of elephant endotheliotropic herpesvirus in captive Asian elephants (Elephas maximus): First case of eehv 4 in Asia. J. Zoo Wildl. Med. 2013, 44, 100-104. [CrossRef]

21. Sripiboon, S.; Angkawanish, T.; Boonprasert, K.; Sombutputorn, P.; Langkaphin, W.; Ditcham, W.; Warren, K. Successful treatment of a clinical elephant endotheliotropic herpesvirus Infection: The dynamics of viral load, genotype analysis, and treatment with acyclovir. J. Zoo Wildl. Med. 2017, 48, 1254-1259. [CrossRef]

22. Azab, W.; Damiani, A.M.; Ochs, A.; Osterrieder, N. Subclinical infection of a young captive Asian elephant with elephant endotheliotropic herpesvirus 1. Arch. Virol. 2018, 163, 495-500. [CrossRef] [PubMed] 
23. Kochagul, V.; Srivorakul, S.; Boonsri, K.; Somgird, C.; Sthitmatee, N.; Thitaram, C.; Pringproa, K. Production of antibody against elephant endotheliotropic herpesvirus (EEHV) unveils tissue tropisms and routes of viral transmission in EEHV-infected Asian elephants. Sci. Rep. 2018, 8, 4675. [CrossRef]

24. Yun, Y.; (Center of Elephant and Wildlife Research, Faculty of Veterinary Medicine, Chiang Mai University, Chiang Mai, Thailand). Personal communication, 2021.

25. Kendall, R.; Howard, L.; Masters, N.; Grant, R. The impact of elephant endotheliotropic herpesvirus on the captive Asian elephant (Elephas maximus) population of the United Kingdom and Ireland (1995-2013). J. Zoo Wildl. Med. 2016, 47, 405-418. [CrossRef] [PubMed]

26. Brown, J.L.; Walker, S.L.; Moeller, T. Comparative endocrinology of cycling and non-cycling Asian (Elephas maximus) and African (Loxodonta africana) Elephants. Gen. Comp. Endocrinol. 2004, 136, 360-370. [CrossRef] [PubMed]

27. Foley, C.A.; Papageorge, S.; Wasser, S.K. Noninvasive stress and reproductive measures of social and ecological pressures in free-ranging African elephants. Conserv. Biol. 2001, 15, 1134-1142. [CrossRef]

28. Möstl, E.; Palme, R. Hormones as indicators of stress. Domest. Anim. Endocrinol. 2002, 23, 67-74. [CrossRef]

29. Millspaugh, J.J.; Burke, T.; Van Dyk, G.; Slotow, R.; Washburn, B.E.; Woods, R.J. Stress response of working African elephants to transportation and safari adventures. J. Wildl. Manag. 2007, 71, 1257-1260. [CrossRef]

30. Dathe, H.H.; Kuckelkorn, B.; Minnemann, D. Salivary cortisol assessment for stress detection in the Asian elephant (Elephas maximus): A pilot study. Zoo Biol. 1992, 11, 285-289. [CrossRef]

31. Laws, N.; Ganswindt, A.; Heistermann, M.; Harris, M.; Harris, S.; Sherwin, C. A case study: Fecal corticosteroid and behavior as indicators of welfare during relocation of an Asian elephant. J. Appl. Anim. Welf. Sci. 2007, 10, 349-358. [CrossRef]

32. Marcilla, A.; Urios, V.; Mauri, M. Welfare assessment of captive Asian elephants (Elephas Maximus) and Indian rhinoceros (Rhinoceros unicornis) using salivary cortisol measurement. Anim. Welf. 2008, 17, 305-312.

33. Menargues, A.; Urios, V.; Limiñana, R.; Mauri, M. Circadian rhythm of salivary cortisol in Asian elephants (Elephas maximus): A factor to consider during welfare assessment. J. Appl. Anim. Welf. Sci. 2012, 15, 383-390. [CrossRef] [PubMed]

34. Bansiddhi, P.; Brown, J.L.; Khonmee, J.; Norkaew, T.; Nganvongpanit, K.; Punyapornwithaya, V.; Angkawanish, T.; Somgird, C.; Thitaram, C. Management factors affecting adrenal glucocorticoid activity of tourist camp elephants in Thailand and implications for elephant welfare. PLoS ONE 2019, 14, e0221537. [CrossRef]

35. Kumar, V.; Pradheeps, M.; Kokkiligadda, A.; Niyogi, R.; Umapathy, G. Non-invasive assessment of physiological stress in captive Asian elephants. Animals 2019, 9, 553. [CrossRef]

36. Staley, M.; Conners, M.G.; Hall, K.; Miller, L.J. Linking stress and immunity: Immunoglobulin A as a non-invasive physiological biomarker in animal welfare studies. Horm. Behav. 2018, 102, 55-68. [CrossRef]

37. Tsujita, S.; Morimoto, K. Secretory IgA in saliva can be a useful stress marker. Environ. Health Prev. Med. 1999, 4, 1-8. [CrossRef]

38. Chintalacharuvu, K.R.; Morrison, S.L. Production of secretory immunoglobulin A by a single mammalian cell. Proc. Natl. Acad. Sci. USA 1997, 94, 6364-6368. [CrossRef] [PubMed]

39. Muneta, Y.; Yoshikawa, T.; Minagawa, Y.; Shibahara, T.; Maeda, R.; Omata, Y. Salivary IgA as a useful non-invasive marker for restraint stress in pigs. J. Vet. Med. Sci. 2010, 72, 1295-1300. [CrossRef]

40. Escribano, D.; Gutiérrez, A.M.; Tecles, F.; Cerón, J.J. Changes in saliva biomarkers of stress and immunity in domestic pigs exposed to a psychosocial stressor. Res. Vet. Sci. 2015, 102, 38-44. [CrossRef]

41. Campos-Rodríguez, R.; Godínez-Victoria, M.; Abarca-Rojano, E.; Pacheco-Yépez, J.; Reyna-Garfias, H.; Barbosa-Cabrera, R.E.; Drago-Serrano, M.E. Stress modulates intestinal secretory immunoglobulin A. Front. Integr. Neurosci. 2013, 7, 86. [CrossRef]

42. Kosaruk, W.; Brown, J.L.; Plangsangmas, T.; Towiboon, P.; Punyapornwithaya, V.; Silva-Fletcher, A.; Thitaram, C.; Khonmee, J.; Edwards, K.L.; Somgird, C. Effect of tourist activities on fecal and salivary glucocorticoids and immunoglobulin A in female captive Asian elephants in Thailand. Animals 2020, 10, 1928. [CrossRef]

43. Casares, M.; Silván, G.; Carbonell, M.D.; Gerique, C.; Martinez-Fernandez, L.; Cáceres, S.; Illera, J.C. Circadian rhythm of salivary cortisol secretion in female zoo-kept African elephants (Loxodonta africana). Zoo Biol. 2016, 35, 65-69. [CrossRef] [PubMed]

44. Plangsangmas, T.; Brown, J.L.; Thitaram, C.; Silva-Fletcher, A.; Edwards, K.L.; Punyapornwithaya, V.; Towiboon, P.; Somgird, C. Circadian rhythm of salivary immunoglobulin A and associations with cortisol as a stress biomarker in captive Asian elephants (Elephas maximus). Animals 2020, 10, 157. [CrossRef] [PubMed]

45. Ng, V.; Koh, D.; Chan, G.; Ong, H.Y.; Chia, S.E.; Ong, C.N. Are salivary immunoglobulin A and lysozyme biomarkers of stress among nurses? J. Occup. Environ. Med. 1999, 41, 920-927. [CrossRef]

46. Edwards, K.L.; Bansiddhi, P.; Paris, S.; Galloway, M.; Brown, J.L. The development of an immunoassay to measure immunoglobulin A in Asian elephant feces, saliva, urine, and serum as a potential biomarker of well-being. Conserv. Physiol. 2019, 7, coy077. [CrossRef] [PubMed]

47. Chuammitri, P.; Srikok, S.; Saipinta, D.; Boonyayatra, S. The effects of quercetin on microRNA and inflammatory gene expression in lipopolysaccharide-stimulated bovine neutrophils. Vet. World 2017, 10, 403-410. [CrossRef] [PubMed]

48. Seilern-Moy, K.; Darpel, K.; Steinbach, F.; Dastjerdi, A. Distribution and load of elephant endotheliotropic herpesviruses in tissues from associated fatalities of Asian elephants. Virus Res. 2016, 220, 91-96. [CrossRef] [PubMed]

49. Almeida, A.; Loy, A.; Hofmann, H. Qqplotr: Quantile-Quantile Plot Extensions for "ggplot2". 2020. Available online: https: / / cran.r-project.org / package=qqplotr (accessed on 11 August 2020). 
50. Pinheiro, J.; Bates, D.; DebRoy, S.; Sarkar, D. Nlme: Linear and Nonlinear Mixed Effects Models. 2020. Available online: https:/ / cran.r-project.org / package=nlme (accessed on 11 August 2020).

51. Reid, C.E.; Hildebrandt, T.B.; Marx, N.; Hunt, M.; Thy, N.; Reynes, J.M.; Schaftenaar, W.; Fickel, J. Endotheliotropic elephant herpes Virus (EEHV) infection. The first PCR-confirmed fatal case in Asia. Vet. Q. 2006, 28, 61-64. [CrossRef]

52. Boyd, J.W. The relationships between blood haemoglobin concentration, packed cell volume and plasma protein concentration in dehydration. Br. Vet. J. 1981, 137, 166-172. [CrossRef]

53. Kim, H.K.; Kim, S.H.; Ryu, J.K. Changes in the blood components caused by water intake. Korean J. Clin. Lab. Sci. 2017, 49, 227-232. [CrossRef]

54. Fielding, C.L.; Magdesian, K.G. Review of packed cell volume and total protein for use in equine practice. In Proceedings of the AAEP Annual Convention-San Antonio, San Antonio, TX, USA, 20 November; 2011; Volume 57, pp. 318-321.

55. Liu, B.; Taioli, E. Seasonal variations of complete blood count and inflammatory biomarkers in the US population-Analysis of NHANES data. PLoS ONE 2015, 10, e0142382. [CrossRef]

56. Lombardi, G.; Ricci, C.; Banfi, G. Effects of winter swimming on haematological parameters. Biochem. Med. 2011, 21, 71-78. [CrossRef] [PubMed]

57. Farooq, U.; Ahmad, N.; Ahmad, I.; Mahmood, S.A.; Andrabi, S.M.; Idris, M. Effect of Seasonal variations on the haematochemical profile of cholistani service bulls. J. Appl. Anim. Res. 2017, 45, 85-89. [CrossRef]

58. Giri, A.; Bharti, V.K.; Kalia, S.; Ravindran, V.; Ranjan, P.; Kundan, T.; Kumar, B. Seasonal changes in haematological and biochemical profile of dairy cows in high altitude cold desert. Indian J. Anim. Sci. 2017, 87, 723-727.

59. Norkaew, T.; Brown, J.L.; Thitaram, C.; Bansiddhi, P.; Somgird, C.; Punyapornwithaya, V.; Punturee, K.; Vongchan, P.; Somboon, N.; Khonmee, J. Associations among tourist camp management, high and low tourist seasons, and welfare factors in female Asian elephants in Thailand. PLoS ONE 2019, 14, e0218579. [CrossRef]

60. Dorsey, C.; Dennis, P.; Guagnano, G.; Wood, T.; Brown, J.L. Decreased baseline fecal glucocorticoid concentrations associated with skin and oral lesions in black rhinoceros (Diceros bicornis). J. Zoo Wildl. Med. Off. Publ. Am. Assoc. Zoo Vet. 2010, 41, 616-625. [CrossRef]

61. Maeda, S.; Ohno, K.; Uchida, K.; Nakashima, K.; Fukushima, K.; Tsukamoto, A.; Nakajima, M.; Fujino, Y.; Tsujimoto, H. Decreased immunoglobulin A concentrations in feces, duodenum, and peripheral blood mononuclear cells of dogs with inflammatory bowel disease. J. Vet. Intern. Med. 2013, 27, 47-55. [CrossRef] [PubMed]

62. Dantzer, R.; Mormède, P. Stress in farm animals: A need for reevaluation. J. Anim. Sci. 1983, 57, 6-18. [CrossRef]

63. Huber, S.; Palme, R.; Arnold, W. Effects of season, sex, and sample collection on concentrations of fecal cortisol metabolites in Red Deer (Cervus elaphus). Gen. Comp. Endocrinol. 2003, 130, 48-54. [CrossRef]

64. Norkaew, T.; Brown, J.L.; Bansiddhi, P.; Somgird, C.; Thitaram, C.; Punyapornwithaya, V.; Punturee, K.; Vongchan, P.; Somboon, N.; Khonmee, J. Body condition and adrenal glucocorticoid activity affects metabolic marker and lipid profiles in captive female elephants in Thailand. PLoS ONE 2018, 13, e0204965. [CrossRef]

65. Mumby, H.S.; Mar, K.U.; Thitaram, C.; Courtiol, A.; Towiboon, P.; Min-Oo, Z.; Htut-Aung, Y.; Brown, J.L.; Lummaa, V. Stress and body condition are associated with climate and demography in Asian elephants. Conserv. Physiol. 2015, 3, cov030. [CrossRef]

66. Brown, J.L.; Paris, S.; Prado-Oviedo, N.A.; Meehan, C.L.; Hogan, J.N.; Morfeld, K.A.; Carlstead, K. Reproductive health assessment of female elephants in north American zoos and association of husbandry practices with reproductive dysfunction in African elephants (Loxodonta africana). PLoS ONE 2016, 11, e0145673. [CrossRef]

67. Rees, A.; Fischer-Tenhagen, C.; Heuwieser, W. Effect of heat stress on concentrations of faecal cortisol metabolites in dairy cows. Reprod. Domest. Anim. 2016, 51, 392-399. [CrossRef] [PubMed]

68. Veissier, I.; Van laer, E.; Palme, R.; Moons, C.P.; Ampe, B.; Sonck, B.; Andanson, S.; Tuyttens, F.A. Heat stress in cows at pasture and benefit of shade in a temperate climate region. Int. J. Biometeorol. 2018, 62, 585-595. [CrossRef] [PubMed]

69. Narayan, E.; Sawyer, G.; Parisella, S. Faecal glucocorticoid metabolites and body temperature in Australian merino ewes (Ovis aries) during summer artificial insemination (AI) program. PLoS ONE 2018, 13, e0191961. [CrossRef] [PubMed]

70. Keay, J.; Singh, J.; Gaunt, M.; Kaur, T. Fecal glucocorticoids, and their metabolites as indicators of stress in various mammalian species: A literature review. J. Zoo Wildl. Med. 2006, 37, 234-244. [CrossRef] [PubMed]

71. Jain, N.C. Essentials of Veterinary Hematology, 1st ed.; Wiley-Blackwell: Philadelphia, PA, USA, 1993; ISBN 978-0-8121-1437-9.

72. Kumar, B.; Pachauri, S.P. Haematological profile of crossbred dairy cattle to monitor herd health status at medium elevation in central himalayas. Res. Vet. Sci. 2000, 69, 141-145. [CrossRef] [PubMed] 